\title{
MANAGEMENT OF A RESTORATIVE RESTRUCTURING PROJECT WITH THE USE OF REENGINEERING METHODS - CASE STUDY OF A PUMP PRODUCTION ENTERPRISE
}

\author{
Katarzyna WYBRAŃCZYK \\ Silesian University of Technology, Faculty of Organization and Management; wybranczykprofilpsi@op.pl, \\ ORCID: 0000-0002-2437-6032
}

Purpose: The subject of interest of this article is reengineering and restructuring. The purpose of the article is to answer the question: is remedial restructuring carried out using reengineering methods more efficient, i.e. is a greater percentage of the assumed restructuring goals achieved in a given unit of time than in a project carried out without using this method?

Design/methodology/approach: The process of restructuring management described in the article is supported by a case study of a company dealing with production of pumps. The case study shows how effective the reengineering method is for managing corrective change. The restructuring project described in the article was aimed at eliminating unproductive processes in the company, and then leading to the development of the company by conducting organizational changes and radical rebuilding of the company's business processes.

Findings: Conclusions from the case study analysis provide clear evidence that remedial restructuring using reengineering is much more efficient than in a traditional project.

Originality/value: The article supplements knowledge in the field of change management. The conclusions presented in it regarding the usefulness of the reengineering method when conducting remedial processes in enterprises can be used by change managers as an indication to successfully carry out restructuring implementations.

Keywords: project management, remedial restructuring, business process reengineering, reengineering.

\section{Introduction}

Enterprises operate in an economic environment that is undergoing constant change. If the environment changes, then enterprises must keep up with these changes. Sometimes this requires companies to carry out the restructuring process. The article discusses the issue of restorative restructuring, which is carried out in enterprises at the time of their crisis. Changes that are made in organizations are made either by managers of a given company or by external consulting companies. Implementation of restructuring changes takes place in various ways. 
At the beginning of the work, an analysis of the company's state is carried out, during which a recovery plan is set. Changes can be implemented by managers, by delegating topics related to changes to their employees, or by engaging employees to work together on solutions. The method related to employee involvement in implementation works, which was described in this article, is based on the assumptions of the reengineering process. This article presents a case study of one of Polish enterprises that was restructured. The purpose of this article is to answer the question: is the restorative restructuring carried out with the use of reengineering methods more efficient, i.e. whether a higher percentage of the assumed restructuring goals is achieved in a given unit of time than in a project carried out without using this method? The article includes information on restorative restructuring and the process of reengineering. The next part contains a case study. On its basis, a comparative analysis was made, which shows which implementation method is the most effective. The ending of the article consists of conclusions drawn from the performed comparative analysis.

\section{Restorative restructuring}

Enterprises operating in the economic environment are subject to continuous development challenges and the need to modify unprofitable processes (Kmieciak, 2013; Pakulska, 2016; Koźmiński, 2002). The phenomenon of globalization and computerization has made these changes an indispensable condition for the operation of most enterprises (Malara, 2007). Therefore, it is important to properly prepare the enterprise for changes and to carry out corrective implementations in the most effective way. The notion of restructuring is associated with the concept of change in the context of an enterprise. Restructuring means modern, often radical changes made in enterprises, including significant areas of economic activity, which are aimed at improving the efficiency and effectiveness of operations (Borowiecki, 2014).

In order for the company's restructuring to give the expected result, it must be carefully planned and then carried out in accordance with the developed program, but it should also be adequately controlled by the people managing the restructuring process (Jagoda, 1994). One of the significant restructuring methods is restorative restructuring. Its goal is to improve the financial condition of the company by making appropriate changes in enterprises. In any organization, the need to implement changes should be adapted to diagnosed needs (Bainbridge, 1996). However, common in any restorative restructuring is the process of its implementation, which is as follows:

1) identification of the need for restructuring,

2) assessment of the current situation in the enterprise (diagnosis of indicators),

3) defining the objectives and scope of restructuring,

4) strategic analysis of the company, 
5) developing a restructuring plan,

6) implementation of the plan, deployment (Sapiszka, 1996).

Analysis and explanation of the current situation of the company, analysis of the company's economic situation and the initial concept of new conditions for the functioning of the organization, should give an idea of what changes should be made in the enterprise. Then an analysis is carried out on: external environment of the enterprise, legal and financial status, products and services, internal organization of the enterprise and assessment of the current situation. These are aimed at:

1. The analysis of the company's external environment is to determine the external conditions of the company's operations: attractiveness of the industry, competitiveness, and the pace of the industry's development. These factors can decide about investing and size of production.

2. Legal analysis of the company concerns: legal analysis of property components, claims, liabilities, other liabilities related to long-term contracts.

3. Financial analysis aims at a comprehensive and reliable diagnosis of the actual economic and financial condition of the company and assessment of its ability to generate profits. Its subject matter is to measure and assess the level of profitability and profitability in the global system, the degree of financial liquidity. An analysis of both assets and liabilities is made, with particular emphasis on liabilities (Garstka, 2006).

4. Assessment of the current situation is a summary of the current analysis. SWOT analysis is often made here. If the restructuring is carried out by an external company, the participant observation method is also used here, during which the auditors parameterize the performance of employees, production lines, analyse bottlenecks, etc.

5. The next stage is to summarize the above data and determine the detailed directions of restructuring. This stage includes the definition of new or modification of the existing strategy and detailed objectives for the company. Strategic goals arise from the nature of restructuring and boil down to the survival of an enterprise or to improving its market position. Then a restructuring plan is being prepared. This plan should include a description of the necessary changes in all areas of the company's operation resulting from the diagnosis made.

The enterprise restructuring program is, on the one hand, a report on the analysis and strategic assessment of the company's situation, on the other it is an implementation project, constituting the basis for implementing appropriate changes in the enterprise (Nalepka, 1999; Slatter, 2001). 


\section{Reengineering}

Proper management of the restructuring project will influence whether the indicators of restructuring success, mentioned in the report, will be achieved or not (Suszyński, 2003). Managers or external companies who are responsible for making changes in the company use different management methods to properly implement this project. One of the methods used to implement changes during restructuring is the so-called reengineering. It involves changing the concept of enterprise thinking from traditional to process thinking. The basis of this approach is the assumption that the company should be treated as a whole of processes oriented at creating value for the customer. The customer here is any process or person who uses the services of a given process (Hammer, Champy, 1996) The concept of reengineering gained popularity in the early 90s of the twentieth century. It was successfully implemented in such companies as: Hall-Mark, Taco Bell, Capital Holding, Bell Atlantic, ABB, Rank-Xerox (Martyniak, 1998). However, there were companies that had to withdraw very quickly from this type of activity, because first and foremost the human factor failed there. The resistance of employees of restructured companies has shown that a company is difficult to change in a revolutionary way. Therefore, this type of project should be properly prepared and introduced taking into account the human factor (Jokiel, 2009). To identify processes, it is necessary to have knowledge that allows identifying, structuring and describing activities occurring in organizations. Wellformed processes are characterized, among others, by:

1. having a goal (value added for the client) and a specific product of the process,

2. having the owner of the process (the person managing the process) and the team that is part of the process,

3. defining the limits and standards of the process,

4. indicators allowing for the estimation of the effectiveness of the process, which means the degree of achievement of the goal (Cyfert, Krzakiewicz, 2008; Jokiel, 2009).

Consulting companies, when carrying out restorative restructuring in enterprises, sometimes use the assumptions of these concepts. They introduce necessary changes in enterprises and modify processes that require working on them. The research phase and the creation of a new concept of change takes between two and five months. The implementation phase that follows then lasts from one to three years. Most often, external consulting companies implement the changes in this area in up to one year's time and enterprises with greater or lesser successes are continuing the process of change themselves. Creating a good reengineering team is extremely important. A manager of such a team is appointed, who is, to some extent, an authority for employees (e.g. a member of the board, an informal leader in the organization, a high-level director respected by others). Next, representatives of the staff are appointed to be assigned to work on the full-time project. Such a team should consist of people who know all processes well, IT specialists, human resources specialists, and other people who know nothing 
about the processes being repaired. The appointed team accomplishes the set goals and is supported by external consultants. Reengineering operations should be carried out gradually, starting with the change of only some processes recognized as particularly important for the company, and then gradually moving to other areas (Toffler, 2006; Brilman, 2002).

\section{The case study}

As an example of the use of the method of reengineering during restructuring, we can use company X (a large enterprise employing over 500 people) that manufactures pumps. When planning its development, the company had to carry out two restructuring processes. The first one was restorative restructuring, and the next - developmental restructuring. The company first focused on eliminating unprofitable outbreaks in the company - which would also improve the company's financial liquidity. In the next step, one can only take care of its development. During the restorative restructuring, the entire company structure was not rebuilt, but process thinking was gradually introduced. It had two goals: 1) employees were slowly being prepared to change their thinking from the standard organizational one to process thinking, 2) too rapid implementation of the process could do more harm than good. Restorative restructuring was carried out by an external consultancy company.

After analysing the company's condition, the external company prepared solutions to problems or topics that were to be implemented to improve the company's operations. It was for example: improvement of production standards by $20 \%$, shortening the circulation of documents by 2 days, implementation of the machine review program before or after the commencement of change, etc. The company $\mathrm{X}$ assumed that each topic to be implemented can be treated as a process that is subject to modification (according to the method of reengineering). Therefore, it was assumed that in order to implement identified problems / themes, the following steps should be performed:

1. Determine the purpose of the repair - solving the problem (assuming that the added value for the client will be achieved, i.e. for another process/project/department that is related to the topic),

2. Identify the owner of the problem/topic and the team that will be responsible for working on this topic,

3. Specify the work schedule for the topic, set the assumptions for implementation in order to achieve the goal,

4. Establish indicators allowing to estimate the effectiveness of work on the subject (degree of goal achievement). 
In order to effectively implement the above-mentioned steps, the aforementioned external company engaged managers of a given company to implement the established assumptions. Restructuring changes were carried out by the companies, therefore at the beginning of the work, only a part of the managers was involved in the repair works. The company's management, knowing the area of work of its managers, informed which managers, due to their competences, can actively implement the change process and which changes must be imposed. Two groups of managers were created in a natural way - they can be called implementation groups.

I. Twenty managers were asked to prepare a list of problems they are struggling with, and those identified by an external company would only complete this list (if they did not replicate). In company $\mathrm{X}$, this group was called the Group $\mathrm{R}$ (from the word reengineering).

II. The second group consisted of 10 managers - Group N (from the Polish word for imposed), on which corrective changes were imposed from above.

The following Action Plan has been developed for the Group R (referred to as the Action Team Action Plan):

1. Managers (both production and administration) were asked to prepare a list of problems with which their departments are struggling.

2. A meeting was organized with the above managers. In order to give the right rank to this meeting, the company's management board was invited. Two hours have been set for the meeting.

3. At the meeting the purpose of the meeting and the agenda were presented. It was established what the next meetings would look like. The appointed team - the Project Team - was named, the head of the team was chosen, who would be responsible for accounting for the effects of work (head of the production or administration department, or a member of the board).

4. At the meeting the managers presented a list with their problems, the external company also added topics to the list - points for changes that were determined after the analysis of the business activity. Priorities have been assigned to these topics. They were: priority A - tasks that include more than one department in the company that should be implemented first, priority $\mathrm{B}$ - tasks that include more than one department in the company that can be implemented as second, and priority $\mathrm{C}$ - tasks that cover only one department in the company - the department decides how fast it should be implemented.

5. Task leaders were indicated at the meeting. The leaders were the managers present at the meeting or chosen from the lower level managers. The dates of the leader's meetings with the person from the external company were set for further work on the subject.

6. The next meeting was established in this group - in a month. The purpose of the next meeting was to account for the leaders from the tasks performed. The person appointed as the manager of the entire team was to coordinate further work. 
7. The designated task leader met with a person from an external company. A problem has been described in great detail to find out what action needs to be taken to solve it. People who were supposed to participate in solving problems were listed - a so-called task team was created and the time was set when the task would be completed.

8. At the next meeting, the entire task team met - the work schedule was established. Tasks were divided.

9. The next meeting - it was a meeting that would account for the effects of work. Teams met once a week and the appointments were once a month.

The following action plan has been developed for Group N (referred to as the Project Team Action Plan):

1. Individuals from an external company met with 10 managers - each one separately.

2. At the meetings, it was agreed what scope of work should be implemented by managers and in what period.

3. Managers together with their teams, with whom they work, were responsible for the implementation of the assigned tasks.

4. After a month, the managers were accounted for completed tasks.

The tasks were carried out after a month and after two months of work of the teams. The following were assumed for the implementation of tasks: the percentage of implementation of tasks set in the schedule. The results are as follows:

\section{In Group R:}

1) After one month: $60 \%$ of tasks were completed on time.

2) After two months: $55 \%$ of tasks completed on time.

II. In Group N:

1) After one month: $30 \%$ of tasks were completed on time.

2) After two months: $35 \%$ of tasks completed on time.

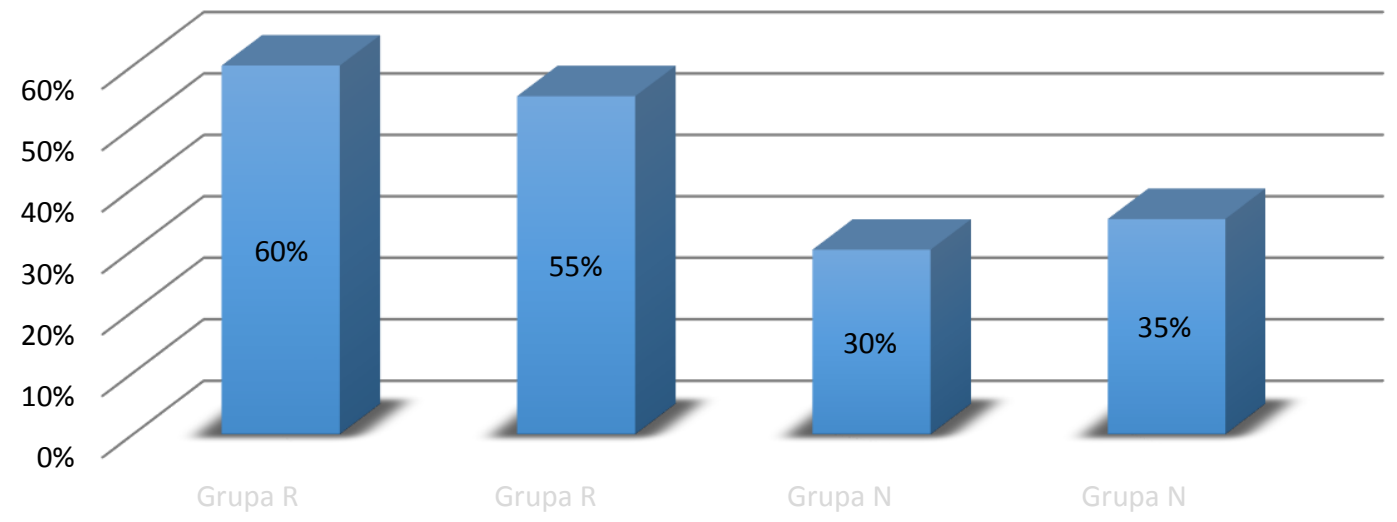

Figure 1. Implementation of tasks after a month and after two months by groups $\mathrm{R}$ and $\mathrm{N}$.

Studies have shown that there is a relationship $(\mathrm{p}<0.001)$ between the way the changes are implemented and the effectiveness of the implementations. 


\section{Conclusions}

In the article it was considered why the implementation of the assumed tasks is not higher. The external company began observing the work of task forces. The conclusions from the observations were as follows: in groups that realized implementation projects in accordance with the assumptions of reengineering (Group R), managers and members of task forces felt responsible for proposing solutions to problems and for their implementation. The gratification from realizing the implementation task itself was enough for them, and that their organizational proposals work and bring the appropriate benefits, e.g. greater production, improvement and availability of work of the machines. In the case of a group that had predetermined activities (Group N), it achieved lower results of tasks for the following reasons: the flow of information in these groups was low, employees felt that they had pre-imposed tasks that they did not completely agree with, employees did not see any benefits from having to implement implementation tasks. The above conclusions gave clear information that the remedial restructuring carried out using the methods of reengineering goes much more efficiently, i.e. a greater percentage of the assumed goals ais achieved in a given unit of time than in the project carried out by traditional methods.

\section{References}

1. Bainbridge, C. (1996) Designing for Change. A Practical Guide to Business Transformation. Chichester: John Wiley\&Sons, p. 42.

2. Borowiecki, R. (ed.) (2014). Zarządzanie restrukturyzacja przedsiębiorstw i gospodarki. Fundacja Uniwersytetu Ekonomicznego w Krakowie, p.14.

3. Brilman, J. (2002) Nowoczesne koncepcje i metody zarządzania. Warszawa: PWE.

4. Cyfert, S., Krzakiewicz, K. (2008) Koncepcja organizacji ukierunkowanej na procesy. In: J. Pyka (ed.), Nowoczesność przemystu i usług. Doskonalenie zarządzania i usług jako źródło przewagi konkurencyjnej. Katowice: TNOiK, p. 199.

5. Garstka, M. (2006). Restrukturyzacja przedsiębiorstwa podziat przez wydzielenie. Warszawa: Cedewu, p. 38-39.

6. Hammer, M., Champy, J. (1996). Reengineering w przedsiębiorstwie. Warszawa: Neumann Management Institute, p. 45-49.

7. Jagoda, H. (1994). Wybrane problemy restrukturyzacji naprawczej przedsiębiorstw. Prace Naukowe AE, Wroctaw, 668, p.37-40.

8. Jokiel, G. (2009). Podejście procesowe w zarządzaniu - geneza i kierunki rozwoju koncepcji. In: S. Nowosielski (ed.), Podejście procesowe w organizacjach, Prace naukowe 
Uniwersytetu Ekonomicznego we Wrocławiu. Wydawnictwo Uniwersytetu Ekonomicznego we Wrocławiu, p. 19-21.

9. Kmieciak, R. (2013). Wpływ otoczenia na funkcjonowanie śląskich małych i średnich przedsiębiorstw. Zeszyty Naukowe Politechniki Ślaskiej. Seria: Organizacja i Zarządzanie, 64.

10. Koźmiński, A.K., Piotrowski, W. (2002). Zarządzanie Teoria i praktyka. PWN, p. 30-31.

11. Malara, Z. (2007). Przedsiębiorstwo w globalnej gospodarce. Wyzwania współczesności. Warszawa: PWN, p. 12-14.

12. Martyniak, Z. (1998). Nowe metody organizacji i zarządzania. Kraków: Akademia Ekonomiczna, p. 33.

13. Nalepka, A. (1999). Restrukturyzacja przedsiębiorstwa. Warszawa: PWN, p. 42.

14. Pakulska, T. (2016) Otoczenie przedsiębiorstwa a rozwój sharing economy. In: M. Poniatowska-Jaksch, R. Sobieck. Sharing Economy (p. 39). Warszawa Oficyna Wydawnicza SGH.

15. Sapiszka, Z. (1996). Restrukturyzacja przedsiębiorstwa. Szanse i ograniczenia. Warszawa: PWN, p. 183.

16. Slatter, S., Lovett, D. (2001). Restrukturyzacja firmy Zarządzanie przedsiębiorstwem w sytuacjach kryzysowych. Warszawa: WIG-Press, p. 171-172.

17. Suszyński, C. (2003). Restrukturyzacja, konsolidacja, globalizacja przedsiębiorstw. PWE, p. 96-101.

18. Toffler, A. (2006). Trzecia fala. Poznań: Wydawnictwo Kurpisz. 